\title{
PEMBERDAYAAN GURU PEMBINA PMR DAN SANTRI MELALUI PELATIHAN PERTOLONGAN PERTAMA PADA KECELAKAAN (P3K)
}

DOI: https://doi.org/10.33024/jkpm.v4i5.4267

\author{
Mokh. Sujarwadi ${ }^{*}$, Ida Zuhroidah², Mukhammad Toha ${ }^{3}$, Nurul Huda ${ }^{4}$ \\ ${ }^{1-3}$ Prodi D3 Keperawatan Fakultas Keperawatan \\ Universitas Jember Kampus Kota Pasuruan
}

Disubmit: 26 April 2021 Diterima: 03 Mei 2021 Diterbitkan: 03 Oktober 2021

Email korespondensi: sujarwadi.akper@unej.ac.id

\begin{abstract}
ABSTRAK
Pertolongan pertama merupakan perawatan pertama yang diberikan sebelum pertolongan medis datang. Prinsip-prinsip P3K adalah tindakan yang dilakukan segera, mempertahankan hidup korban, mengurangi penderitaan, mencegah pengotoran luka dan penderitaan lanjutan serta merujuk korban ke tempat pelayanan kesehatan terdekat. Palang merah remaja merupakan kegiatan remaja di sekolah dalam bentuk extrakulikuler. Tujuan dari kegiatan pengabdian ini adalah meningkatkan pengetahuan guru Pembina PMR dan santri tentang pelatihan pertolongan pertama pada kecelakaan. Metode yang digunakan adalah ceramah, diskusi serta pelatihan. Terjadi peningkatan pengetahuan sebelum dan sesudah dilakukan pelatihan dengan adanya peningkatan pengetahuan $90 \%$ dari hasil pre test. Peserta juga memapu mempraktekkan cara menghentikan perdarahan, pembidaian, perawatan luka serta penanganan gigitan ular.
\end{abstract}

Kata Kunci : pemberdayaan, guru pembina PMR, santri, P3K

\begin{abstract}
First aid is the first treatment given before medical help arrives. The principles of $P 3 \mathrm{~K}$ are actions that are taken immediately, maintain the victim's life, reduce suffering, prevent fouling wounds and further suffering and refer the victim to the nearest health service place. The youth red cross is an activity of youth in schools in the form of extracurricular activities. This service activity aims to increase the knowledge of PMR guidance teachers and students about first aid training. The methods used are lectures, discussions, and training. There was an increase in knowledge before and after training with an increase in knowledge of $90 \%$ from the pre-test results. The participants also practiced how to stop bleeding, splinting, treating wounds, and handling snake bites.
\end{abstract}

Keywords: empowerment of PMR supervisors, students, first aid 


\section{PENDAHULUAN}

Pertolongan pertama merupakan perawatan pertama yang diberikan sebelum pertolongan medis datang. Tujuan pertolongan pertama adalah menyelamatkan jiwa dan dilakuakan dengan cepat serta tepat. Pertolongan pertama diberikan oleh orang yang memberikan bantuan ketika seseorang mengalami cedera (Rini, 2015).

Tujuan dari pertolongan pertama adalah mencegah kondisi yang lebih buruk, tapi tindakan yang di berikan harus tepat dengan dasar pengetahuan yang memadai, Penelitian yang dilakukan oleh (Febrina et al., 2017) ada hubungan pengetahuan anggota PMR dengan tindakan pertolongan pertama pada penderita sinkop, anggota PMR perlu memiliki pengetahuan dalam memberikan pertolongan pertama pada penderita sinkop. Sejalan dengan (Nurul Huda, Ida Zuhroidah, Mukhammad Toha, 2021) bahwa pelatihan tentang P3K dapat meningkatkan pengetahuan santri serta mampu mempraktekkan cara menghentikan serta melakukan balud bidai serta pertolongan pertama pada gigitan ular. Menurut (Damayanti, 2016) pelatihan pertolongan pertama pada kecelakaan, signifikan meningkatkan pengetahuan tentang penanganan fraktur pada anggota PMR. Pada korban kecelakaan, pertolongan pertama diberikan sebelum mendapat pertolongan yang lebih sempurna dari dokter atau tenaga kesehatan yang professional.

Prinsip-prinsip P3K adalah tindakan yang dilakukan segera, mempertahankan hidup korban, mengurangi penderitaan, mencegah pengotoran luka dan penderitaan lanjutan serta merujuk korban ke tempat pelayanan kesehatan terdekat. Prinsip-prinsip P3K ini sangat dianggap perlu bagi semua lapisan masyarakat, karena dengan P3K kita dapat membantu orang atau korban sampai benar-benar mendapat perawatan medis professional. P3K bisa dilakukan oleh baik itu masyarakat umum ataupun siswa, sampai pertolongan medis professional tiba untuk menangani korban (Saubers \& lannelli, 2008). Beberapa pengetahuan dan keterampilan yang diberikan pada saat pelatihan P3K adalah bagaimana kita menangani korban dengan cedera kepala, penanganan korban kecelakaan, memindahkan korban dengan cara yang baik dan benar, penanganan penyakit jantung, penanganan luka bakar, penanganan fraktur tulang, penanganan tenggelam, sampai tentang penanganan jalan nafas.

Palang merah remaja atau PMR adalah bagian dari palang nerah Indonesia (PMI) yang merupakan kegiatan remaja di sekolah melalui kegiatan extrakulikuler (Susilo et al., 2008). Remaja merupakan generasi penerus bangsa, dan merupakan sumber daya manusia yang paling potensial (Amraini et al., 2020). Siswa penting memiliki pengetahuan tentang pertolongan pertama sehingga bisa menolong disi sendiri atau orang lain ketika terjadi cedera di lingkungan sekolah (Ganesan \& Kalaiyarasan, 2015).

Berdasarkan hasil wawancara dengan pengurus Pusat Kesehatan Pondok Pesantren (Puskestren) di PP Bayt Al Hikmah, santri laki-laki yang ikut sebagai anggota PMR belum mengikuti pelatihan P3K Padahal ilmu itu sangat perlu apabila terjadi kegawatdaruratan. Berdasarkan permintaan dari Kepala Puskestren untuk diadakannya pelatihan P3K secara lebih lengkap dan terarah, karena mereka menganggap pelatihan yang diberikan selama ini sangat kurang sekali dan rentang waktu diberikan pelatihan cukup lama yaitu setiap 5 tahun, disamping itu juga jumlah pembina yang dilatih cukup terbatas. Sehingga perlu diadakannya pelatihan-pelatihan tentang P3K yang bersifat formal, dengan tujuan untuk meningkatkan status kesehatan 
disekolah pada khususnya dan status kesehatan masyarakat pondok pesantren pada umumnya.

Pesantren Bayt Al Hikmah mengajarkan ilmu umum serta agama secara imbang dan merupakan pondok pesantren modern. Santri dibekali keterampilan sehingga bermanfaat di keluarga maupun masyarakat (Sujarwadi, Mokh. Toha, M, Zuhroidah, 2021). Santri penting untuk memiliki pengetahuan serta ketrampilan menolong dalam kondisi darurat, karena santri berada di Asrama selama 24 jam (Zuhroidah et al., 2021).

Kegiatan pemberdayaan guru PMR dan anggota PMR ini bertujuan meningkatkan motivasi, pengetahuan, ketrampilan dalam pertolongan pertama pada kecelekaan yang terjadi di lingkungan pesantren.

\section{MASALAH}

Sesuai dengan surat permohonan dari kepala Puskestren, maka kami melakukan kegiatan pengabdian ini di Pondok Pesantren Bayt Al Hikmah. Jumlah petugas kesehatan 4 dengan jumlah santri lebih darii 1.000, dimana santri berada di pondok selama 24 jam. Asrama yang terdiri dari 4 lantai beresiko terjadi cedera pada santri, sedangkan lokasi pelayanan kesehatan tidak bisa di jangkau dalam waktu cepat. Dengan adanya pemberdayaan pada anggota PMR diharapkan mereka segera memberikan pertolongan pertama ketika terjadi kecelakaan pada santri yang lain.

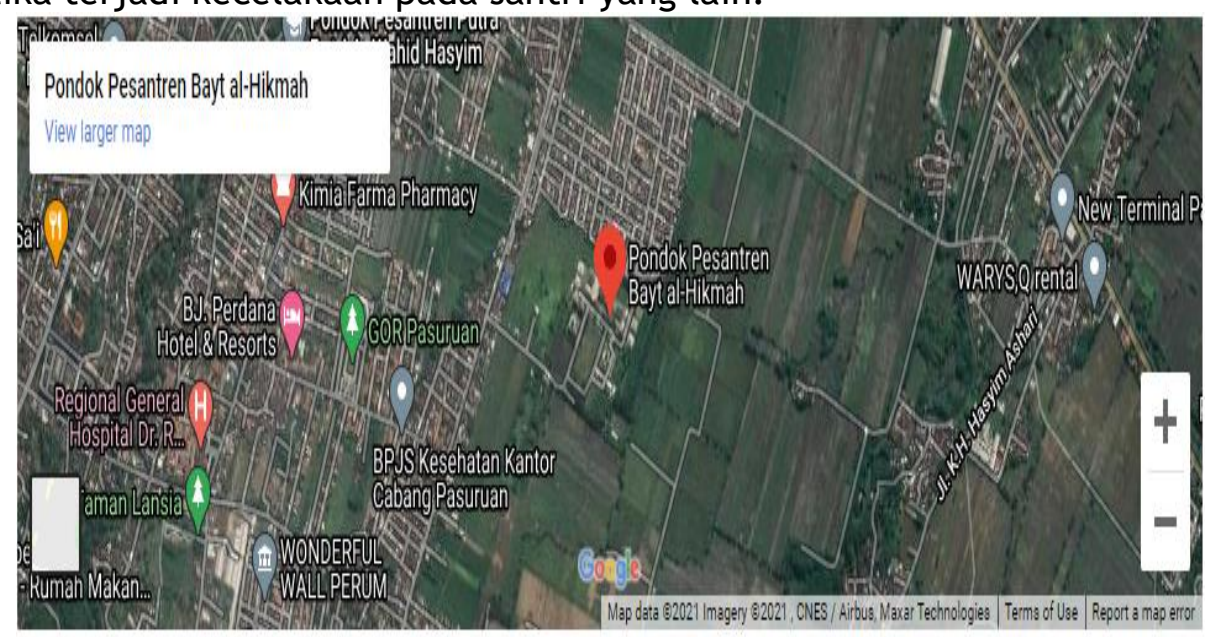

Gambar 2.1 Peta Lokasi Kegiatan

\section{METODE}

Metode yang dipergunakan dalam kegiatan pemberdayaan ini adalah ceramah, diskusi, metode pelatihan dengan pendekatan modelling serta demonstrasi. Kegiatan ini di awali dengan pembukaan dari kepala pusat kesehatan pesantren, perkenalan, menyampaikan tujuan dari kegiatan selama 2 hari, melakukan apersepsi dengan melakukan pre test berupa soal multiple choice yang diberikan kepada santri. Kegiatan selanjutnya adalah menyampaikan materi tentang pertolongan pertama pada kecelakaan dengan alat peraga dan model, melakukan demontrasi pertolongan pertama pada kecelakaan, diskusi tentang semua materi yang sudah di sampaikan, member kesempatan santri untuk melakukan redemontrasi. Media yang digunakan adalah LCD, alat balut bidai, spalk. Di akhir sesi, santri di berikan soal post test serta di minta untuk memperagakan cara menghentikan perdarahan dan pembidaian, serta perawatan luka dan penanganan gigitan ular. 


\section{HASIL DAN PEMBAHASAN}

Kegiatan pemberdayaan ini dilaksanakan selama 2 hari,di ikuti oleh 2 guru Pembina PMR serta santri putra anggota PMR. Materi pelatihan yang diberikan meliputi pertolongan pertama pada kecelakaan yang meliputi patah tulang, cedera otot, jaringan lunak, cara mbalut bidai, perawatan luka dan penanganan gigitan ular. Materi yang disampaikan meliputi materi yang sering terjadi pada santri di lingkungan pondok pesantren. Peserta sangat antusias mengikuti kegiatan pelatihan selama dua hari dimana 100\% peserta mengikuti kegiatan sejak awal sampai akhir kegiatan. Seluruh peserta antusias dalam mengikuti materi, diskusi serta saat praktek serta seluruh peserta serius mengikuti kegiatan selama 2 hari. Pengetahuan dan ketrampilan santri Putra serta guru Pembina PMR meningkat di ukur dengan pre test dan post test, dimana terjadi peningkatan nilai post test dimana soal pre test dan post sama beripa multiple choice. Penelitian yang dilakukan oleh (Najihah \& Ramli, 2019) ada pengaruh pendidikan kesehatan P3K terhadap pengetahuan penangan fraktur pada anggota PMR di SMA Gowa. Ada hubungan yang signifikan antara update pelatihan dengan tindakan pertolongan pertama dalam tiga tahun terakhir dimana nilai $p<0.005$ (Karaca \& Kose, 2020).Terjadinya peningkatan pengetahuan peserta setelah mengikuti pelatihan selama 2 hari bisa meningkatkan motivasi serta kepercayaan diri sehingga ketika ada kecelakaan di lingkungan pesantren bisa segera melakukan pertolongan secara cepat dan tepat. Kegiatan pemberdayaan pada guru Pembina PMR dan anggota PMR terdokumentasi pada gambar berikut:

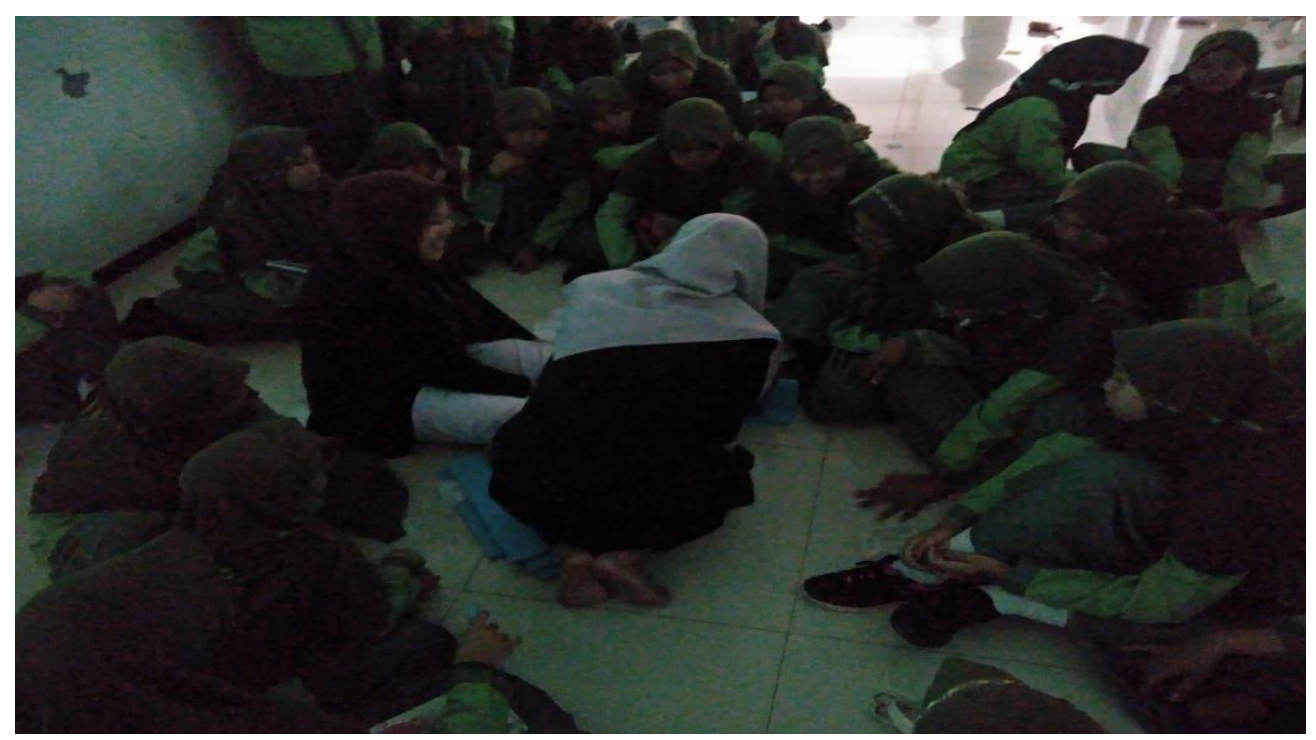

GGambar 4.1 Demontrasi 


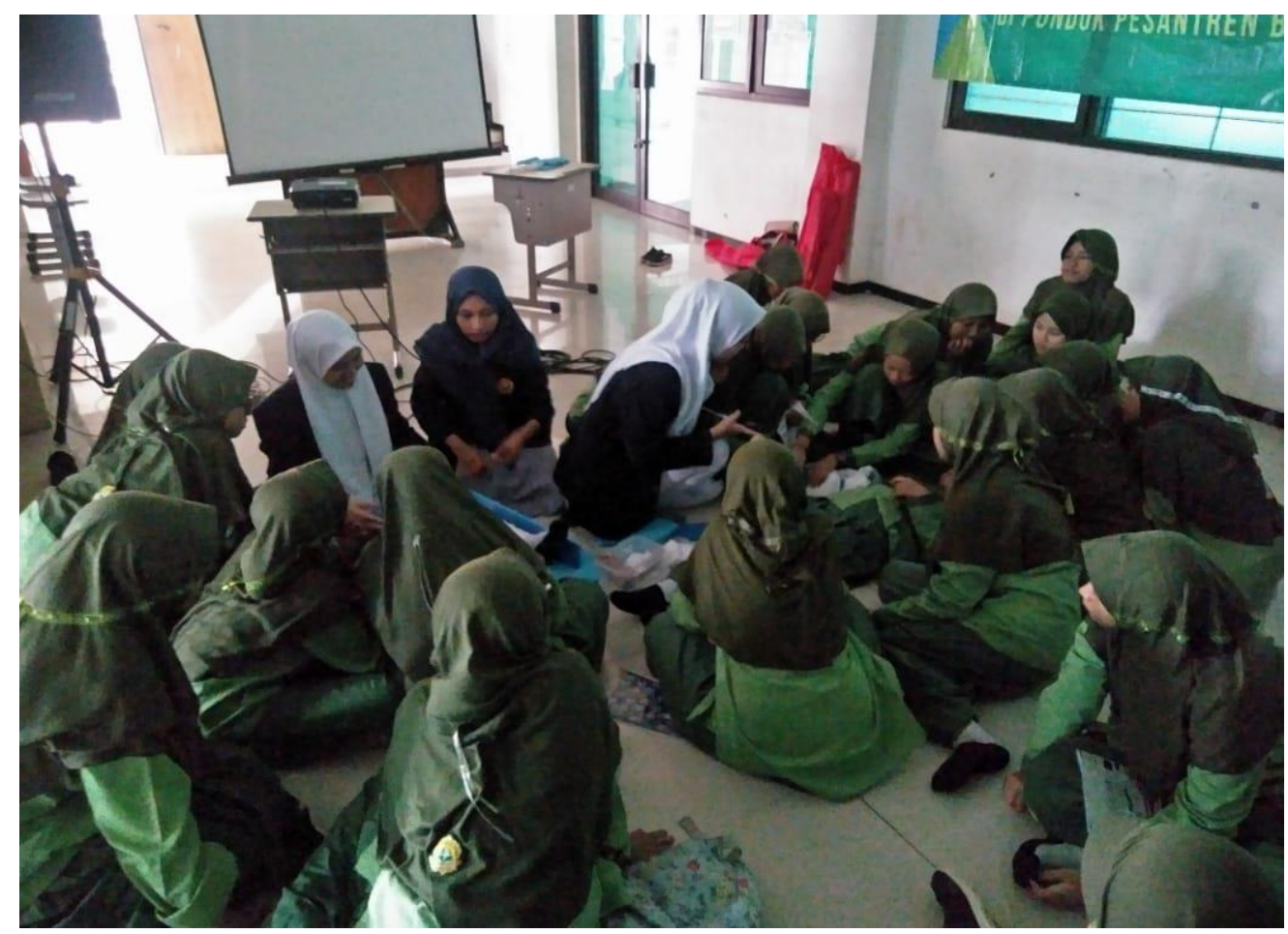

Gambar 4.2 Redemontrasi

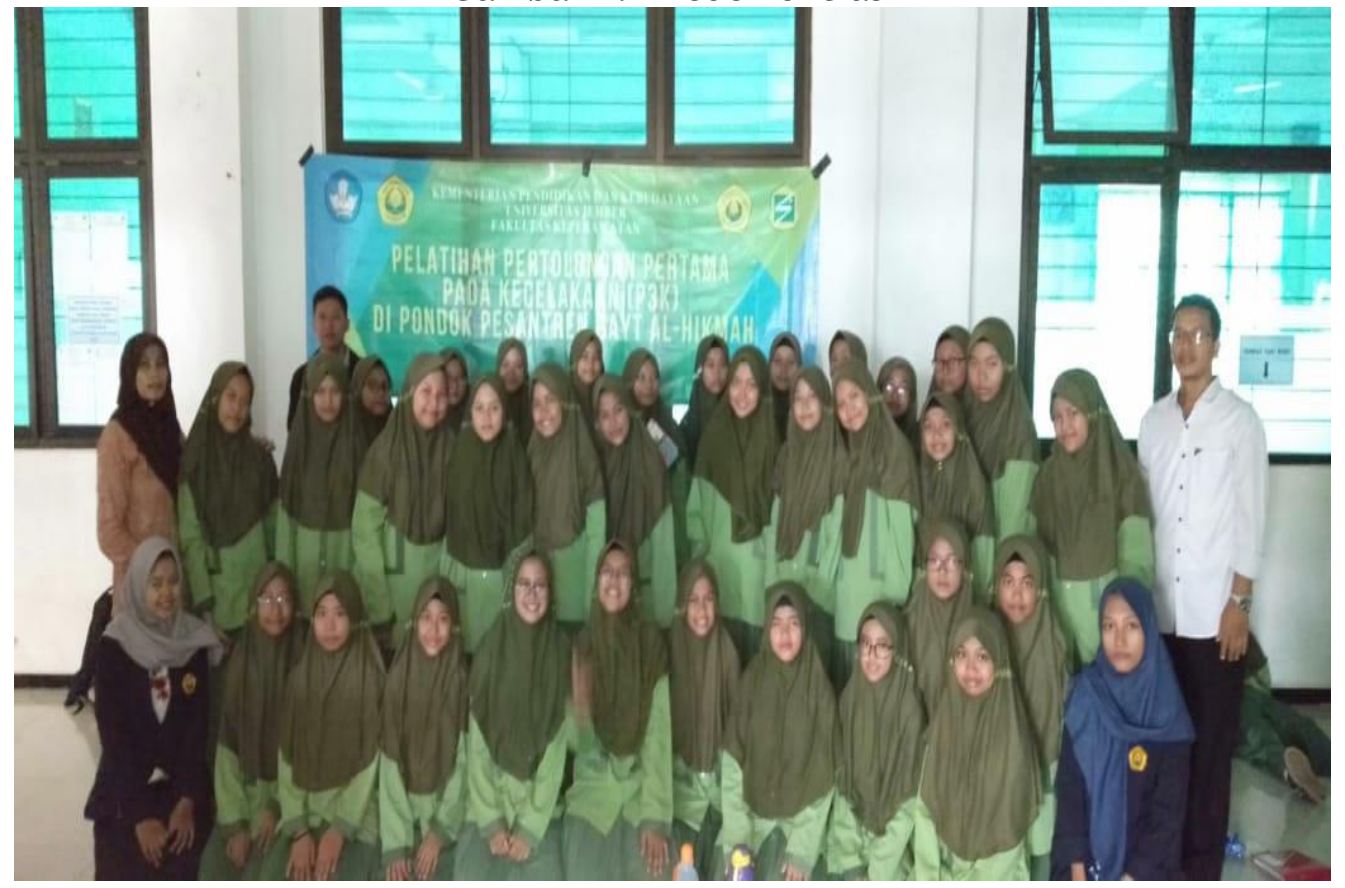

Gambar 4.3 Foto Bersama

\section{KESIMPULAN}

Kegiatan pelatihan ini berjalan dengan lancar karena ada kerjasama dari pihak pesantren, serta siswa sehingga tujuan pelatihan bisa tercapai. Kegiatan ini di ikuti oleh peserta mulai awal sampai akhir (100\%). Terjadinya perubahan pengetahuan sebelum dan sesudah pelatihan di ukur dengan soal pre test dan post test. Diharapkan kegiatan pengabdian ini berlanjut terus dengan kegiatan pendampingan serta harapan kedepannya terbentuk modul tentang P3K di lingkungan pesantren yang di buat oleh guru Pembina PMR. 


\section{DAFTAR PUSTAKA}

Amraini, A., Yanti, D. E. , \& Sari, N. (2020). Hubungan Citra Tubuh, Pengetahuan Gizi dan Perilaku Makan terhadap Status Gizi Remaja di SMA Negeri 5 Kota Metro tahun 2017. Jurnal Dunia Kesmas, 9(2), 264-269. https: //doi.org/10.33024/jdk.v9i2.2916

Damayanti, I. (2016). Pengaruh Pemberian Pelatihan Pertolongan Pertama Pada Kecelakaan Terhadap Pengetahuan Penanganan Fraktur Pada Siswa Anggota Pmr Di Sma Negeri 1 Binangun [STIKES Gembong]. In Skripsi. http://elib.stikesmuhgombong.ac.id/id/eprint/199

Febrina, V., Semiarty, R., \& Abdiana, A. (2017). Hubungan Pengetahuan Siswa Palang Merah Remaja dengan Tindakan Pertolongan Pertama Penderita Sinkop di Madrasah Tsanawiyah Negeri 1 Bukittinggi. Jurnal Kesehatan Andalas, 6(2), 435. https://doi.org/10.25077/jka.v6i2.717

Ganesan, K., \& Kalaiyarasan, G. (2015). A Study on First Aid Awareness among Higher Secondary School Students in Sivagangai District. International Journal of Multidisciplinary Approach and Studies. https: / / www.researchgate.net/publication/339377007

Karaca, A., \& Kose, S. (2020). The effect of knowledge levels of individuals receiving basic first aid training in Turkey on the applications of first aid. Nigerian Journal of Clinical Practice, 23(10), 1449-1455. https://doi.org/10.4103/njcp.njcp_686_19

Najihah, \& Ramli, R. (2019). Pendidikan Kesehatan Pertolongan Pertama pada Kecelakaan Meningkatkan Pengetahuan Anggota PMR tentang Penanganan Fraktur. Jurnal Penelitian Kesehatan Suara Forikes, 10(2), 151-154. http: / / forikes-ejournal.com/index.php/SF

Nurul Huda, Ida Zuhroidah, Mukhammad Toha, M. S. (2021). Pelatihan Pertolongan Pertama Pada Kecelakaan (P3K) Pada Guru Pembina dan Anggota PMR. Jurnal Kreativitas Pengabdian Kepada Masyarakat (PkM), 4(2), 323-328. https://doi.org/https://doi.org/10.33024/jkpm.v4i2.3746

Rini, S. (2015). Jurus Rahasia Menguasai P3K. EGC.

Saubers, N., \& lannelli, V. (2008). The Everything First Aid Book (Issue 1). Adams Media, Massachusetts.

Sujarwadi, Mokh. Toha, M, Zuhroidah, I. (2021). Penguatan Perilaku New Normal Covid 19 Melalui Kontrol Teman Sebaya. Jurnal Kreativitas Pengabdian Kepada Masyarakat (PkM), 4(2), 334-338. https://doi.org/https://doi.org/10.33024/jkpm.v4i2.3739

Susilo, J., Mulyadi, A., \& Utami, R. (2008). Palang Merah Remaja. Wikipedia. https://id.wikipedia.org/wiki/Palang_Merah_Remaja

Zuhroidah, I., Toha, M., Sujarwadi, M., \& Huda, N. (2021). Pengabdian Kepada Masyarakat Bantuan Hidup Dasar Pada Santri. Jurnal Kreativitas Pengabdian Kepada Masyarakat (Pkm), 4(2), 329-333. https://doi.org/10.33024/jkpm.v4i2.3733 